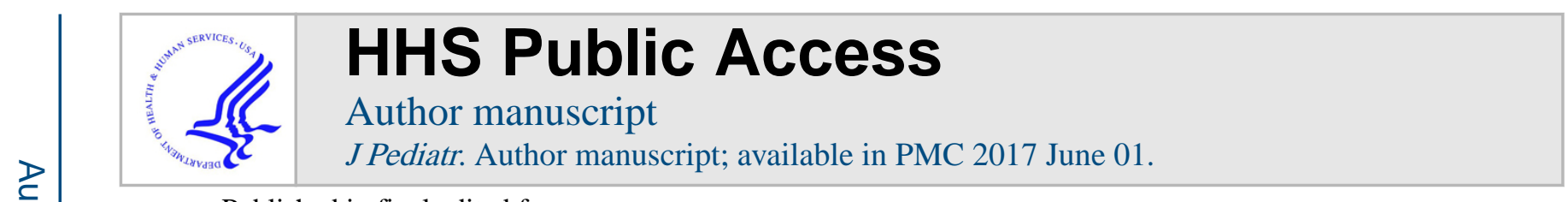

Published in final edited form as:

J Pediatr. 2016 June ; 173: 32-38. doi:10.1016/j.jpeds.2016.02.068.

\title{
The Biology of Stature
}

Youn Hee Jee, M.D. and Jeffrey Baron, M.D.

Section on Growth and Development, Eunice Kennedy Shriver National Institute of Child Health and Human Development, National Institutes of Health

\section{Keywords}

Growth; growth plate; growth plate senescence; chondrogenesis; short stature; genome wide association study; whole-exome sequencing

\begin{abstract}
Most pediatricians are attuned to their patients' linear growth (height gain). At each visit, the child's height should be carefully measured and plotted. The clinician can then scrutinize the temporal pattern, and, if the linear growth appears abnormal, initiate an investigation to uncover the underlying problem. Despite this close interest in our patients' statural gains, linear growth itself is often considered as a "black box", a mysterious process regulated by nutrition, hormones, genetics, and overall health. Recently, there have been exciting advances in understanding the biological basis of linear growth. We have gained new insights as to why linear growth is rapid in infancy, then slows in childhood, accelerates in adolescence, then slows again and ceases by adulthood. We now understand much better the mechanisms by which hormones, nutrition, and systemic illness regulate linear growth. Perhaps most exciting, genome-wide association (GWA) studies and whole-exome sequencing have begun to identify numerous novel genes that regulate linear growth, and, when mutated, cause childhood growth disorders.
\end{abstract}

To understand these important new findings and their implications for our patients, we must look inside the black box of linear growth. Just as we can only understand children's respiratory physiology in terms of lung biology, so too we can only understand linear growth and growth disorders in terms of the underlying biological process, growth plate chondrogenesis.

\section{Clinical vignette}

A 6-year-old boy presents for evaluation of short stature. He was born at term with a length and weight appropriate for gestational age. By two years of age, his length percentile had dropped below the third percentile. Weight was less affected. He has been otherwise healthy.

Corresponding author: Jeffrey Baron, MD, Phone: 301-496-6312, Fax: 301-402-0574, ; Email: jeffrey.baron@ nih.gov, National Institutes of Health, CRC, Room 1-3330, 10 Center Drive MSC 1103, Bethesda, MD 20892-1103

Publisher's Disclaimer: This is a PDF file of an unedited manuscript that has been accepted for publication. As a service to our customers we are providing this early version of the manuscript. The manuscript will undergo copyediting, typesetting, and review of the resulting proof before it is published in its final citable form. Please note that during the production process errors may be discovered which could affect the content, and all legal disclaimers that apply to the journal pertain.

The authors declare no conflicts of interest. 
His mother and father are both $160 \mathrm{~cm}$ (63 in) tall. On physical examination, the boy's height is below the first percentile at -2.2 SDS. His sitting to standing height ratio is at the 95th percentile for age. His father's sitting to standing height ratio is greater than the 95th percentile for age.

In this review we will discuss a variety of novel concepts which will aid in the assessment of children such as this. We will see now this child's condition altered body proportions indicate that the condition affects the growth plates in the lower extremities more than the growth plates of the vertebrae. This disproportion suggests a primary linear growth condition, i.e. an underlying mechanism that is intrinsic to the growth plate. The similar phenotype of the father suggests a dominant inheritance. Targeted sequencing by a commercial laboratory showed a mutation in SHOX, which encodes a transcription factor required for normal growth plate chondrocyte function. Heterozygous SHOX mutations account for approximately 2-5\% of children with formerly idiopathic short stature. SHOX lies on the $\mathrm{X}$ chromosomes, but, unlike most $\mathrm{X}$-chromosome genes, a second copy is present on the Y chromosome in boys, and consequently SHOX mutations are inherited in a pseudoautosomal pattern.

\section{Linear growth in children is driven by growth plate chondrogenesis}

Children grow taller because their bones grow longer. This bone elongation occurs at the growth plate, a cartilaginous structure that is located near the ends of many bones in children, including long bones, the short tubular bones of the hands and feet, and the vertebrae. The growth plate comprises three distinct layers: the resting, proliferative and hypertrophic zones (Figure 1). Each zone has unique roles. The resting zone serves as a reservoir of progenitor chondrocytes (1). The proliferative zone, which contains chondrocytes arrayed in columns, is the site of rapid cell proliferation (Figure 1)(2). At the edge of the proliferative zone closest to the metaphysis, the cells stop dividing and become enlarged to form hypertrophic chondrocytes (Figure 1)(2). This cell proliferation and cell hypertrophy, combined with extracellular matrix secretion, result in chondrogenesis, that is, the production of more and more cartilage (2). In isolation, this chondrogenesis would cause the cartilaginous growth plate to become progressively wider with age. However, simultaneously, blood vessels, osteoclasts, and osteoblasts invade the hypertrophic zone and remodel the newly formed cartilage into bone (2). The net result is that new bone is formed at the boundary between the growth plate and the metaphysis, causing the bones to grow longer and the child to grow taller.

\section{Linear growth is rapid in infancy but subsequently slows due to programmed senescence of the growth plate}

The human fetus grows rapidly. From 12 weeks of gestation until term, the length of the fetus increases from approximately $6 \mathrm{~cm}$ to $50 \mathrm{~cm}$, an average growth velocity of $82 \mathrm{~cm} /$ year (3). If newborns were to maintain this growth rate after birth, the child would reach adult size before two years of age. However, the growth rate declines rapidly after birth. The decline is temporarily interrupted by the pubertal growth spurt but then resumes until the growth rate reaches zero (Figure 2)(4). 
The decline in the linear growth rate during childhood appears to be driven primarily by local mechanisms within the growth plate, rather than by systemic mechanisms. There are no growth-regulating hormones whose concentration changes in a pattern that would explain the decline in growth rate. For example, the concentration of IGF-I actually increases with age during childhood (5). Furthermore, growth plates have been transplanted between rabbits of different ages, and the growth rate of the transplanted growth plates depends on the age of the donor, not the recipient, suggesting that the decline in growth rate is due to a local, growth plate mechanism, rather than a systemic mechanism (6).

Recent studies have identified a developmental program intrinsic to the growth plate cartilage, termed "growth plate senescence", which is responsible for the decline in growth rate with age. With increasing age, the growth plate gradually involutes, so that the number of cells in each zone diminishes (7-9). Concurrently, the rate of proliferation and the extent of cell hypertrophy diminish (7-8), causing the child's linear growth to slow. Eventually, proliferation ceases altogether, and the non-functional growth plate is resorbed and replaced by bone, an event termed epiphyseal fusion or growth plate closure (Figure 2)(10). Thus, epiphyseal fusion does not cause growth cessation, as is often assumed, but instead fusion is the result of growth cessation (11). Growth plate senescence appears to be driven by an extensive genetic program that involves the downregulation with age of many growthpromoting genes (12). A related growth-limiting genetic program occurs in other tissues, causing somatic growth also to slow and eventually cease in other major organ systems (13-15).

In children, the progression of growth plate senescence can be indirectly assessed from a radiograph of the left hand and wrist. On these radiographs, the child's bone age is evaluated by observing the extent to which the cartilage skeletal elements have been converted into bone. The bone age appears to serve as a radiological marker for growth plate senescence in that it predicts the amount of linear growth remaining and therefore helps predict the adult height.

\section{Variations in tempo of growth including catch-up growth}

Importantly, growth plate senescence is not driven by time but rather by the process of growth itself $(7,16)$. Consequently, childhood malnutrition or systemic illness slows not just the rate of linear growth, but also the rate of growth plate senescence $(7,17)$. If the illness resolves, the growth plates do not just resume a normal growth rate normal. Instead, the growth plates, which are less senescent than normal for age, function at the more rapid rate that would be appropriate for a younger child, resulting in catch-up growth (7, 16-18). Previously, catch-up growth had been thought to result from a central nervous system mechanism (19), but recent studies favor this local mechanism $(7,16-18)$ involving delayed growth plate senescence, although it remains unclear if other mechanisms also contribute (20).

The pace of growth plate senescence also appears to vary among healthy children and to be associated with the child's overall tempo of maturation. For example, some otherwise healthy children show a slow overall tempo of maturation, with slower childhood growth, 
delayed puberty, and continued growth into late adolescence. In this condition, termed constitutional delay of growth and puberty, the presence of prolonged growth and a delayed bone age, even prior to puberty, suggests that the pace of growth plate senescence is also slowed. This condition appears to be familial, suggesting a genetic basis. In some children, the delay in maturation appears to be driven by subtle undernutrition due to diminished appetite $(21,22)$.

\section{The pubertal growth spurt}

As reviewed above, a local developmental program termed growth plate senescence causes the linear growth velocity in children to decline through infancy and childhood, reaching 5 $\mathrm{cm} /$ per year just before the onset of puberty (Figure 2)(4). However, with puberty, the gonads increase production of sex steroids which exert strong positive effects on linear growth (Figure 2). Estrogen contributes to the linear growth acceleration, in part by stimulating secretion of growth hormone by the pituitary gland (23). Androgen, either from the adrenal glands or gonads, appears to contribute to the pubertal growth spurt in part through conversion to estrogens by the enzyme aromatase, but androgen also appears to have a stimulatory effect on the growth plate which is not mediated by conversion to estrogen or by increased growth hormone (24). This effect may explain the growth-stimulating effect of androgens that cannot be converted to estrogens, for example, oxandrolone treatment in Turner syndrome (25).

Estrogen exerts another important effect on the growth plate; it accelerates growth plate senescence apparently by depleting the pool of chondrocyte progenitor cells (8). This phenomenon has important clinical implications. Early exposure to estrogen, in children with precocious puberty, causes not only accelerated growth, but also accelerated growth plate senescence (reflected by an advanced bone age) and consequently early cessation of growth, early epiphyseal fusion, and a diminished adult stature (26). Conversely, delayed puberty slows growth plate senescence (reflected by a delayed bone age), causing delayed growth cessation, delayed epiphyseal fusion, and an augmented adult stature (27). Similar effects are seen in men with either estrogen resistance due to mutations in the estrogen receptor ER-a or with estrogen deficiency due to mutations in the enzyme aromatase, which is required for estrogen synthesis by converting androgen to estrogen, both of whom continue to grow gradually well into adulthood, resulting in marked tall stature (28-29). The recognition of this effect of estrogen on the growth plate has given rise to a new experimental treatment for short stature in boys, using aromatase inhibitors (30) although the long term efficacy and safety are not yet established.

\section{Short and tall stature are caused by altered rates of growth plate chondrogenesis}

Because linear growth in children is primarily driven by growth plate chondrogenesis, short stature is essentially always caused by decreased chondrogenesis in the growth plate and tall stature by increased chondrogenesis. The primary causes of short or tall stature can lie either in the growth plate itself (primary linear growth condition) or can lie outside the growth plate but affect chondrocytes through abnormal concentrations of hormones, cytokines, 
nutrients, and other molecules necessary for normal chondrocyte function (secondary linear growth condition).

\section{Regulation of linear growth}

The rate of growth plate chondrogenesis, and therefore the rate of linear growth in children, is subject to extensive regulation by nutritional intake, hormones, inflammatory cytokines, paracrine growth factors, extracellular matrix factors, and intracellular proteins.

\section{Nutritional intake}

Both inadequate and excessive nutritional intake alter longitudinal bone growth. In nutritional deficiency, much of the effect appears to be mediated by endocrine factors: decreased IGF-I, sex steroids, and thyroid hormone and increased glucocorticoids, as may be observed in children with anorexia nervosa (31). In nutritional excess causing obesity, linear growth may be accelerated, resulting in tall stature and advanced bone age, but the adult height is not substantially affected (32). The underlying mechanisms remain poorly understood.

\section{Hormones}

Thyroid hormone, growth hormone, insulin-like growth factor-I (IGF-I), androgen, and estrogen all positively regulate linear growth. Consequently, deficiency of these hormones can present clinically with decreased linear growth (33-35). In contrast, glucocorticoid in excess negatively regulates linear growth, accounting for the poor linear growth of children with endogenous or exogenous Cushing syndrome (36). Each of these hormones acts in part through a direct, local effect on growth plate chondrogenesis (37-40), although there are also complex interactions among these systems; for example, thyroid hormone and estrogen positively regulate growth hormone secretion $(23,40-41)$.

\section{Inflammatory cytokines}

TGF- $\beta$, IL- $1 \beta$, and IL- 6 all negatively regulate growth plate chondrogenesis. There is evidence for both direct, local actions on growth plate chondrocytes as well as indirect actions, involving IGF-I suppression (42). These adverse effects of circulating proinflammatory cytokines likely contribute to the linear growth impairment in children with inflammatory bowel disease or juvenile idiopathic arthritis (42-43).

\section{Paracrine growth factors}

Multiple paracrine growth factors are produced locally in the growth plate, and these paracrine growth factors, including IGFs, C-natriuretic peptide (CNP), bone morphogenetic proteins (BMPs) and fibroblast growth factors (FGFs), affect adjacent chondrocytes by acting on specific cell-surface receptors (44-47). Consequently, patients with mutations in genes involved in these signaling systems can present with linear growth failure or overgrowth (Table). For example, homozygous inactivating mutations in NPR2, the receptor for CNP, cause a skeletal dysplasia with severe short stature (48), whereas heterozygous inactivating mutations present as idiopathic short stature (49-50) and activating mutations produce tall stature (51-52). 


\section{Extracellular matrix}

The extracellular matrix of growth plate cartilage is composed of collagens (including collagen II and X), proteoglycans (including aggrecan and perlecan) and non-collagenous proteins (including cartilaginous oligomeric matrix protein)(53). Mutations affecting these proteins can present clinically either as short stature with minimal bone deformity, as seen in heterozygous aggrecan mutations, or as a skeletal dysplasia as seen in collagen type 10 or cartilaginous oligomeric matrix protein (Table)(54-55).

\section{Intracellular proteins}

Transcription factors such as RUNX2, SOX9 and SHOX play major roles in growth plate chondrogenesis. For example, mutations in RUNX2 cause cleidocranial dysplasia and mutations in SOX-9 cause campomelic dysplasia (56-57). Homozygous mutations in SHOX cause severe short stature in Langer mesomelic dysplasia, whereas heterozygous mutations can present as a milder skeletal dysplasia, Leri-Weill dyschondrosteosis, or more commonly as "idiopathic" short stature with or without disproportion (58). Heterozygous SHOX deficiency is also the principal cause of short stature in Turner syndrome because the SHOX gene is located in the pseudoautosomal region of the X-chromosome. Genes that affect epigenetic modifications have emerged as a cause of overgrowth syndromes (59). For example, mutations in histone methyltransferases EZH2 and NSD1 cause Weaver syndrome and Sotos syndrome respectively (60-61).

\section{Short stature can result from numerous genetic defects affecting growth plate chondrogenesis}

As discussed above, growth plate chondrogenesis is under complex regulation at multiple levels, including nutritional, endocrine, cytokine, paracrine, extracellular matrix, and intracellular protein factors. Consequently, mutations in genes that participate in any of these levels of regulation can result in short stature. Even a mutation that diminishes growth plate chonodrogenesis by only $10 \%$ will produce clinically-significant short stature. The Table provides examples of the genetic causes of short stature that affect growth plate chondrogenesis locally. Depending on the nature of the gene involved, the number of alleles affected, and the severity of the mutation, the short stature can be proportionate or disproportionate, syndromic or non-syndromic, prenatal or postnatal in onset, and associated with skeletal malformation (a chondrodysplasia) or not. Often, specific manifestations of the genetic defect can aid in clinical diagnosis, for example, dysmorphic facies in Noonan syndrome, increased sitting/standing height ratio in SHOX deficiency (62) or hypochondroplasia (63), short $4^{\text {th }}$ and $5^{\text {th }}$ metacarpal bones in Albright hereditary osteodystrophy (64), or early-onset osteoarthritis due to aggrecan mutations (54). Specific genetic testing has become increasingly available at commercial diagnostic laboratories. Recently whole-exome sequencing has emerged as a powerful new approach to identify novel genetic causes of growth disorders. Exome sequencing employs high-throughput sequencing techniques to detect mutations in exons (65). Over the 5-year period since its first application, exome sequencing has identified novel mutations in known genes to cause growth disorders and also discovered mutations in genes not previously implicated in 
childhood growth, either in subjects with syndromic short stature such as CEP152 mutations in Seckel syndrome (66) and CCDC8 mutations in 3M syndrome (67) or patients presenting with non-syndromic short stature, such as ACAN mutations (54).

\section{Normal variation in height and polygenic short stature}

Recent GWA studies have provided important new insights into the genetic determinants of stature. Large meta-analyses of GWA studies have identified more than 400 loci scattered throughout the genome that are associated with adult height in the general population (68). Although the precise gene that affects height at each locus cannot always be pinpointed, bioinformatics analyses indicate that a large subset of these genes affect height because of a role in growth plate cartilage (68-69). Although these genes were identified because they modulate height within the normal range, it seems likely that polymorphisms in these genes may also result in polygenic short stature (70).

\section{Conclusion}

Growth plate chondrogenesis is the fundamental biological process that drives linear growth in children and therefore determines stature. Recently, a complex cartilage developmental program, termed growth plate senescence, has been elucidated which is responsible for the normal deceleration and eventual cessation of linear growth. Recent laboratory and clinical studies have revealed that estrogen accelerates growth plate senescence, thus explaining the clinical growth patterns seen in patients with precocious and delayed puberty and patients treated with aromatase inhibitors to prolong linear growth. Powerful new genetic approaches, including whole-exome sequencing and GWA studies, have helped identify new genes that regulate growth plate chondrogenesis. Polymorphisms in these genes modulate height within the normal range and likely contribute to polygenic short stature, whereas more severe mutations in these genes may present as isolated short stature, syndromic short stature, or skeletal dysplasia.

Understanding the biology of stature provides the clinician with a broad framework to conceptual the myriad of conditions that present with short and tall stature. In the near future, it seems likely that the diagnostic approach to children with severe short or tall stature will include whole-exome or whole-genome sequencing. By conceptualizing linear growth in terms of the underlying growth plate biology, the clinician will be better equipped to interpret the resultant genetic findings.

\section{Acknowledgments}

Supported by the Intramural Research Program of the Eunice Kennedy Shriver National Institute of Child Health and Human Development.

\section{References}

1. Abad V, Meyers JL, Weise M, Gafni RI, Barnes KM, Nilsson O, et al. The role of the resting zone in growth plate chondrogenesis. Endocrinology. 2002; 143:1851-7. [PubMed: 11956168]

2. Kember NF, Walker KV. Control of bone growth in rats. Nature. 1971; 229:428-9. [PubMed: 4927000] 
3. Robinson HP. Sonar measurement of fetal crown-rump length as means of assessing maturity in first trimester of pregnancy. Br Med J. 1973; 4:28-31. [PubMed: 4755210]

4. Tanner JM, Davies PS. Clinical longitudinal standards for height and height velocity for North American children. J Pediatr. 1985; 107:317-29. [PubMed: 3875704]

5. Juul A, Holm K, Kastrup KW, Pedersen SA, Michaelsen KF, Scheike T, et al. Free insulin-like growth factor I serum levels in 1430 healthy children and adults, and its diagnostic value in patients suspected of growth hormone deficiency. J Clin Endocrinol Metab. 1997; 82:2497-502. [PubMed: 9253324]

6. Stevens DG, Boyer MI, Bowen CV. Transplantation of epiphyseal plate allografts between animals of different ages. J Pediatr Orthop. 1999; 19:398-403. [PubMed: 10344328]

7. Marino R, Hegde A, Barnes KM, Schrier L, Emons JA, Nilsson O, et al. Catch-up growth after hypothyroidism is caused by delayed growth plate senescence. Endocrinology. 2008; 149:1820-8. [PubMed: 18174286]

8. Nilsson O, Weise M, Landman EB, Meyers JL, Barnes KM, et al. Evidence that estrogen hastens epiphyseal fusion and cessation of longitudinal bone growth by irreversibly depleting the number of resting zone progenitor cells in female rabbits. Endocrinology. 2014; 155:2892-9. [PubMed: 24708243]

9. Gruber HE, Rimoin DL. Quantitative histology of cartilage cell columns in the human costochondral junction: findings in newborn and pediatric subjects. Pediatr Res. Feb.1989 25:202-4. [PubMed: 2919136]

10. Weise M, De-Levi S, Barnes KM, Gafni RI, Abad V, Baron J. Effects of estrogen on growth plate senescence and epiphyseal fusion. Proc Natl Acad Sci U S A. 2001; 98:6871-6. [PubMed: 11381135]

11. Parfitt AM. Misconceptions (1): epiphyseal fusion causes cessation of growth. Bone. 2002; 30:337-9. [PubMed: 11856639]

12. Lui JC, Andrade AC, Forcinito P, Hegde A, Chen W, Baron J, et al. Spatial and temporal regulation of gene expression in the mammalian growth plate. Bone. 2010; 46:1380-90. [PubMed: 20096814]

13. Finkielstain GP, Forcinito P, Lui JC, Barnes KM, Marino R, Makaroun S, et al. An extensive genetic program occurring during postnatal growth in multiple tissues. Endocrinology. 2009; 150:1791-800. [PubMed: 19036884]

14. Lui JC, Forcinito P, Chang M, Chen W, Barnes KM, Baron J. Coordinated postnatal downregulation of multiple growth-promoting genes: evidence for a genetic program limiting organ growth. FASEB J. 2010; 24:3083-92. [PubMed: 20371622]

15. Delaney A, Padmanabhan V, Rezvani G, Chen W, Forcinito P, Cheung CS, et al. Evolutionary conservation and modulation of a juvenile growth-regulating genetic program. J Mol Endocrinol. 2014; 52:269-77. [PubMed: 24776848]

16. Forcinito P, Andrade AC, Finkielstain GP, Baron J, Nilsson O, Lui JC. Growth-inhibiting conditions slow growth plate senescence. J Endocrinol. 2011; 208:59-67. [PubMed: 20974641]

17. Emons JA, Boersma B, Baron J, Wit JM. Catch-up growth: testing the hypothesis of delayed growth plate senescence in humans. J Pediatr. 2005; 147:843-6. [PubMed: 16356444]

18. Lui JC, Nilsson O, Baron J. Growth plate senescence and catch-up growth. Endocr Dev. 2011; 21:23-9. [PubMed: 21865751]

19. Tanner JM. Regulation of growth in size in mammals. Nature. 1963; 199:845-50. [PubMed: 14079891]

20. de Wit CC, Sas TC, Wit JM, Cutfield WS. Patterns of catch-up growth. J Pediatr. 2013; 162:41520. [PubMed: 23153864]

21. Wudy SA, Hagemann S, Dempfle A, Ringler G, Blum WF, Berthold LD, et al. Children with idiopathic short stature are poor eaters and have decreased body mass index. Pediatrics. 2005; 116:e52-7. [PubMed: 15995019]

22. Murray PG, Read A, Banerjee I, Whatmore AJ, Pritchard LE, Davies RA, et al. Reduced appetite and body mass index with delayed puberty in a mother and son: association with a rare novel sequence variant in the leptin gene. Eur J Endocrinol. 2011; 164:521-7. [PubMed: 21296922] 
23. Martínez AS, Domené HM, Ropelato MG, Jasper HG, Pennisi PA, Escobar ME, et al. Estrogen priming effect on growth hormone $(\mathrm{GH})$ provocative test: a useful tool for the diagnosis of $\mathrm{GH}$ deficiency. J Clin Endocrinol Metab. 2000; 85:4168-72. [PubMed: 11095449]

24. Keenan BS, Richards GE, Ponder SW, Dallas JS, Nagamani M, Smith ER. Androgen-stimulated pubertal growth: the effects of testosterone and dihydrotestosterone on growth hormone and insulin-like growth factor-I in the treatment of short stature and delayed puberty. J Clin Endocrinol Metab. 1993; 76:996-1001. [PubMed: 8473416]

25. Menke LA, Sas TC, de Muinck Keizer-Schrama SM, Zandwijken GR, de Ridder MA, Odink RJ, et al. Efficacy and safety of oxandrolone in growth hormone-treated girls with turner syndrome. J Clin Endocrinol Metab. 2010; 95:1151-60. [PubMed: 20061421]

26. Weise M, Flor A, Barnes KM, Cutler GB Jr, Baron J. Determinants of growth during gonadotropinreleasing hormone analog therapy for precocious puberty. J Clin Endocrinol Metab. 2004; 89:1037. [PubMed: 14715835]

27. Uriarte MM, Baron J, Garcia HB, Barnes KM, Loriaux DL, Cutler GB Jr. The effect of pubertal delay on adult height in men with isolated hypogonadotropic hypogonadism. J Clin Endocrinol Metab. 1992; 74:436-40. [PubMed: 1449545]

28. Rochira V, Carani C. Aromatase deficiency in men: a clinical perspective. Nat Rev Endocrinol. 2009; 5:559-68. [PubMed: 19707181]

29. Smith EP, Boyd J, Frank GR, Takahashi H, Cohen RM, Specker B, et al. Estrogen resistance caused by a mutation in the estrogen-receptor gene in a man. N Engl J Med. 1994; 331:1056-61. [PubMed: 8090165]

30. Dunkel L. Use of aromatase inhibitors to increase final height. Mol Cell Endocrinol. 2006; 254-255:207-16. [PubMed: 16766117]

31. Misra M, Klibanski A. Endocrine consequences of anorexia nervosa. Lancet Diabetes Endocrinol. 2014; 2:581-92. [PubMed: 24731664]

32. Fennoy I. Effect of obesity on linear growth. Curr Opin Endocrinol Diabetes Obes. 2013; 20:44-9. [PubMed: 23222851]

33. Goodman HG, Grumbach MM, Kaplan SL. Growth and growth hormone. II. A comparison of isolated growth-hormone deficiency and multiple pituitary-hormone deficiencies in 35 patients with idiopathic hypopituitary dwarfism. N Engl J Med. 1968; 278:57-68. [PubMed: 4169047]

34. Woods KA, Camacho-Hübner C, Savage MO, Clark AJ. Intrauterine growth retardation and postnatal growth failure associated with deletion of the insulin-like growth factor I gene. N Engl J Med. Oct 31.1996 335:1363-7. [PubMed: 8857020]

35. Rivkees SA, Bode HH, Crawford JD. Long-term growth in juvenile acquired hypothyroidism: the failure to achieve normal adult stature. N Engl J Med. 1988; 318:599-602. [PubMed: 3344006]

36. McArthur RG, Hayles AB, Salassa RM. Growth retardation in Cushing disease. J Pediatr. 1980; 96:783-4. [PubMed: 7359298]

37. Baron J, Huang Z, Oerter KE, Bacher JD, Cutler GB Jr. Dexamethasone acts locally to inhibit longitudinal bone growth in rabbits. Am J Physiol. Sep.1992 263:E489-92. [PubMed: 1415528]

38. Dobie R, Ahmed SF, Staines KA, Pass C, Jasim S, MacRae VE, et al. Increased linear bone growth by GH in the absence of SOCS2 is independent of IGF-1. J Cell Physiol. 2015; 230:2796-806. [PubMed: 25833299]

39. Yakar S, Isaksson O. Regulation of skeletal growth and mineral acquisition by the GH/IGF-1 axis: Lessons from mouse models. Growth Horm IGF Res. 2015; S1096-6374:30031-9.

40. Williams GR. Thyroid hormone actions in cartilage and bone. Eur Thyroid J. 2013; 2:3-13. [PubMed: 24783033]

41. Avtanski D, Novaira HJ, Wu S, Romero CJ, Kineman R, Luque RM, et al. Both estrogen receptor $\alpha$ and $\beta$ stimulate pituitary GH gene expression. Mol Endocrinol. 2014; 28:40-52. [PubMed: 24284820]

42. Sederquist B, Fernandez-Vojvodich P, Zaman F2, Sävendahl L. Recent research on the growth plate: Impact of inflammatory cytokines on longitudinal bone growth. J Mol Endocrinol. 2014; 53:T35-44. [PubMed: 24711646]

43. Kearsley-Fleet L, Hyrich KL, Davies R, Lunt M, Southwood TR, British Society for Paediatric and Adolescent Rheumatology Etanercept Cohort Study. Growth in children and adolescents with 
juvenile idiopathic arthritis over 2 years of treatment with etanercept: results from the British Society for Paediatric and Adolescent Rheumatology Etanercept Cohort Study. Rheumatology (Oxford). 2015; 54:1279-85. [PubMed: 25638806]

44. Wang Y, Cheng Z, Elalieh HZ, Nakamura E, Nguyen MT, et al. IGF-1R signaling in chondrocytes modulates growth plate development by interacting with the PTHrP/Ihh pathway. J Bone Miner Res. 2011; 26:1437-46. [PubMed: 21312270]

45. Nakao K, Osawa K, Yasoda A, Yamanaka S, Fujii T, Kondo E, Koyama N, et al. The Local CNP/GC-B system in growth plate is responsible for physiological endochondral bone growth. Sci Rep. 2015; 5:10554. [PubMed: 26014585]

46. Minina E, Kreschel C, Naski MC, Ornitz DM, Vortkamp A. Interaction of FGF, Ihh/Pthlh, and BMP signaling integrates chondrocyte proliferation and hypertrophic differentiation. Dev. Cell. 2002; 3:439-449. [PubMed: 12361605]

47. Lazarus JE, Hegde A, Andrade AC, Nilsson O, Baron J. Fibroblast growth factor expression in the postnatal growth plate. Bone. 2007; 40:577-586. [PubMed: 17169623]

48. Bartels CF, Bükülmez H, Padayatti P, Rhee DK, van Ravenswaaij-Arts C, et al. Mutations in the transmembrane natriuretic peptide receptor NPR-B impair skeletal growth and cause acromesomelic dysplasia, type Maroteaux. Am J Hum Genet. 2004; 75:27-34. [PubMed: 15146390]

49. Hisado-Oliva A, Garre-Vázquez AI, Santaolalla-Caballero F, Belinchón A, Barreda-Bonis AC, et al. Heterozygous NPR2 Mutations Cause Disproportionate Short Stature, Similar to Léri-Weill Dyschondrosteosis. J Clin Endocrinol Metab. 2015; 100:E1133-42. [PubMed: 26075495]

50. Vasques GA, Amano N, Docko AJ, Funari MF, Quedas EP, Nishi MY, et al. Heterozygous mutations in natriuretic peptide receptor-B (NPR2) gene as a cause of short stature in patients initially classified as idiopathic short stature. J Clin Endocrinol Metab. 2013; 98:E1636-44. [PubMed: 24001744]

51. Miura K, Namba N, Fujiwara M, Ohata Y, Ishida H, Kitaoka T, et al. An overgrowth disorder associated with excessive production of cGMP due to a gain-of-function mutation of the natriuretic peptide receptor 2 gene. PLoS One. 2012; 7:e42180. [PubMed: 22870295]

52. Hannema SE, van Duyvenvoorde HA, Premsler T, Yang RB, Mueller TD, Gassner B, et al. An activating mutation in the kinase homology domain of the natriuretic peptide receptor- 2 causes extremely tall stature without skeletal deformities. J Clin Endocrinol Metab. 2013; 98:E1988-98. [PubMed: 24057292]

53. Myllyharju J. Extracellular matrix and developing growth plate. Curr Osteoporos Rep. 2014; 12:439-45. [PubMed: 25212565]

54. Nilsson O, Guo MH, Dunbar N, Popovic J, Flynn D, Jacobsen C, Lui JC, et al. Short stature, accelerated bone maturation, and early growth cessation due to heterozygous aggrecan mutations. J Clin Endocrinol Metab. 2014; 99:E1510-8. [PubMed: 24762113]

55. Mäkitie O, Susic M, Cole WG. Early-onset metaphyseal chondrodysplasia type Schmid associated with a COL10A1 frame-shift mutation and impaired trimerization of wild-type a1(X) protein chains. J Orthop Res. 2010; 28:1497-501. [PubMed: 20872587]

56. Zhang YW, Yasui N, Ito K, Huang G, Fujii M, Hanai J, et al. A RUNX2/PEBP2alpha A/CBFA1 mutation displaying impaired transactivation and Smad interaction in cleidocranial dysplasia. Proc Natl Acad Sci U S A. 2000; 97:10549-54. [PubMed: 10962029]

57. Yao B, Wang Q, Liu CF, Bhattaram P, Li W, Mead TJ, et al. The SOX9 upstream region prone to chromosomal aberrations causing campomelic dysplasia contains multiple cartilage enhancers. Nucleic Acids Res. 2015; 43:5394-408. [PubMed: 25940622]

58. Binder G. Short stature due to SHOX deficiency: genotype, phenotype, and therapy. Horm Res Paediatr. 2011; 75:81-9. [PubMed: 21325865]

59. Tatton-Brown K, Seal S, Ruark E, Harmer J, Ramsay E, Del Vecchio Duarte S, et al. Childhood Overgrowth Consortium, van Montfort R, Rahman N. Mutations in the DNA methyltransferase gene DNMT3A cause an overgrowth syndrome with intellectual disability. Nat Genet. 2014; 46:385-8. [PubMed: 24614070]

60. Gibson WT, Hood RL, Zhan SH, Bulman DE, Fejes AP, Moore R, et al. Mutations in EZH2 cause Weaver syndrome. Am J Hum Genet. 2012; 90:110-8. [PubMed: 22177091] 
61. Kurotaki N, Imaizumi K, Harada N, Masuno M, Kondoh T, Nagai T, et al. Haploinsufficiency of NSD1 causes Sotos syndrome. Nat Genet. 2002; 30:365-6. [PubMed: 11896389]

62. Malaquias AC, Scalco RC, Fontenele EG, Costalonga EF, Baldin AD, Braz AF, et al. The sitting height/height ratio for age in healthy and short individuals and its potential role in selecting short children for SHOX analysis. Horm Res Paediatr. 2013; 80:449-56. [PubMed: 24296787]

63. Pinto G, Cormier-Daire V, Le Merrer M, Samara-Boustani D, Baujat G, Fresneau L, et al. Efficacy and safety of growth hormone treatment in children with hypochondroplasia: comparison with an historical cohort. Horm Res Paediatr. 2014; 82:355-63. [PubMed: 25323764]

64. Simpson C, Grove E, Houston BA2. Pseudopseudohypoparathyroidism. Lancet. 2015; 21385:1123. [PubMed: 25484027]

65. Ng SB, Bigham AW, Buckingham KJ, Hannibal MC, McMillin MJ, Gildersleeve HI, et al. Exome sequencing identifies MLL2 mutations as a cause of Kabuki syndrome. Nat Genet. 2010; 42:7903. [PubMed: 20711175]

66. Kalay E, Yigit G, Aslan Y, Brown KE, Pohl E, Bicknell LS, et al. CEP152 is a genome maintenance protein disrupted in Seckel syndrome. Nat Genet. 2011; 43:23-6. [PubMed: 21131973]

67. Hanson D, Murray PG, O'Sullivan J, Urquhart J, Daly S, Bhaskar SS, et al. Exome sequencing identifies CCDC8 mutations in 3-M syndrome, suggesting that CCDC8 contributes in a pathway with CUL7 and OBSL1 to control human growth. Am J Hum Genet. 2011; 89:148-53. [PubMed: 21737058]

68. Wood AR, Esko T, Yang J, Vedantam S, Pers TH, Gustafsson S, Chu AY. Defining the role of common variation in the genomic and biological architecture of adult human height. Nat Genet. 2014; 46:1173-86. [PubMed: 25282103]

69. Lui JC, Nilsson O, Chan Y, Palmer CD, Andrade AC, Hirschhorn JN, et al. Synthesizing genomewide association studies and expression microarray reveals novel genes that act in the human growth plate to modulate height. Hum Mol Genet. 2012; 21:5193-201. [PubMed: 22914739]

70. Chan Y, Holmen OL, Dauber A, Vatten L, Havulinna AS, Skorpen F, et al. Common variants show predicted polygenic effects on height in the tails of the distribution, except in extremely short individuals. PLoS Genet. 2011; 7:e1002439. [PubMed: 22242009] 


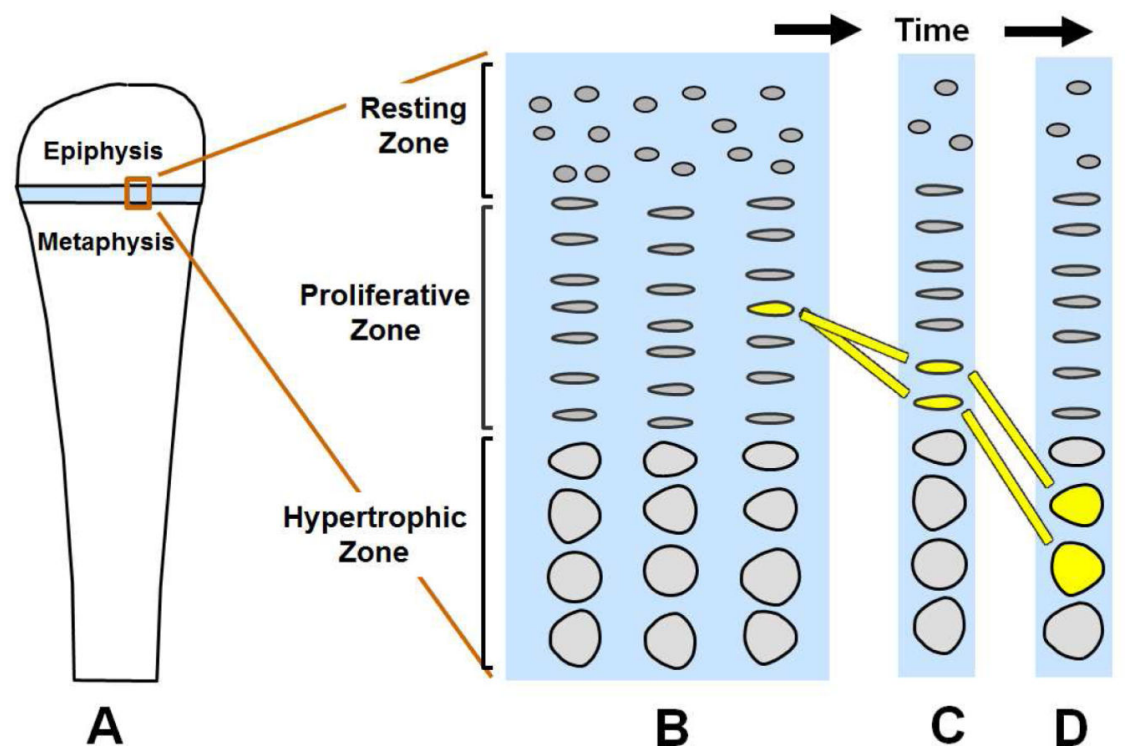

Figure 1. Growth plate chondrogenesis diagram

A. Growth plate (light blue) lies near the end of a long bone B. Enlarged view of the growth plate illustrating its 3 constituent zones, each containing chondrocytes. C. Over time, the proliferative zone chondrocytes, which are arranged in columns, undergo cell divisions (yellow bars trace a single cell over time). D. When chondrocytes reach the border of the proliferative zone closest to the metaphysis, they cease proliferating and instead hypertrophy. Proliferation, hypertrophy, and extracellular matrix secretion contribute to chondrogenesis (cartilage formation). At the boundary of the growth plate and the metaphysis, the newly formed cartilage is remodeled into bone (not shown). 


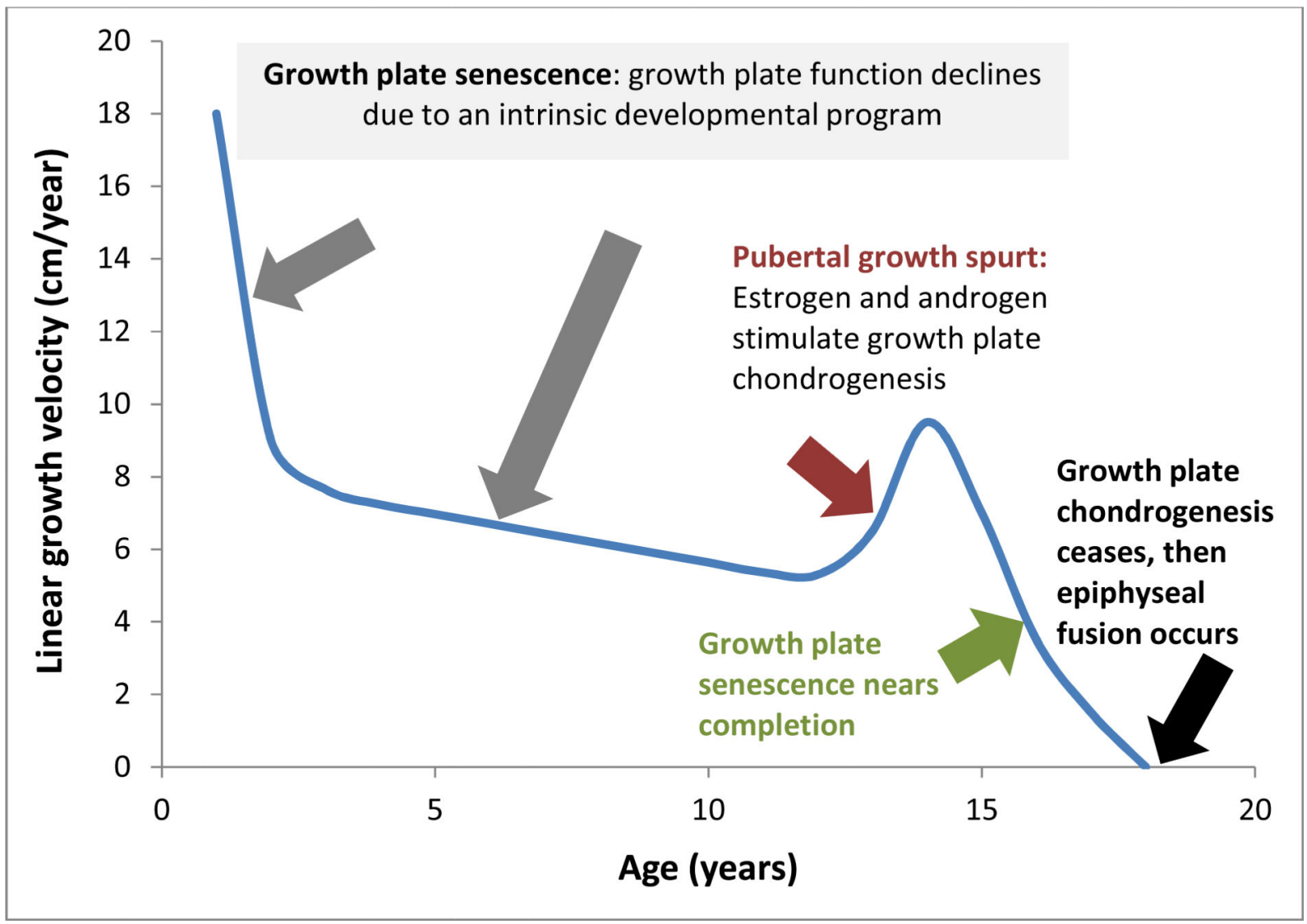

Figure 2. Changes in linear growth velocity with age

The linear growth velocity (change in body length per year) is rapid in infancy, declines in childhood, accelerates in adolescence, and then declines again and ceases by adulthood. The principal mechanisms responsible for these changes are shown. The Figure represents the typical growth pattern for a boy. Girls usually show an earlier growth spurt and earlier cessation of growth. The timing of the pubertal growth spurt and the cessation of growth are often shifted to the right in malnutrition, chronic systemic disease, and in healthy children with a slow developmental tempo. Conversely, a shift to the left occurs in children with a rapid developmental tempo. 


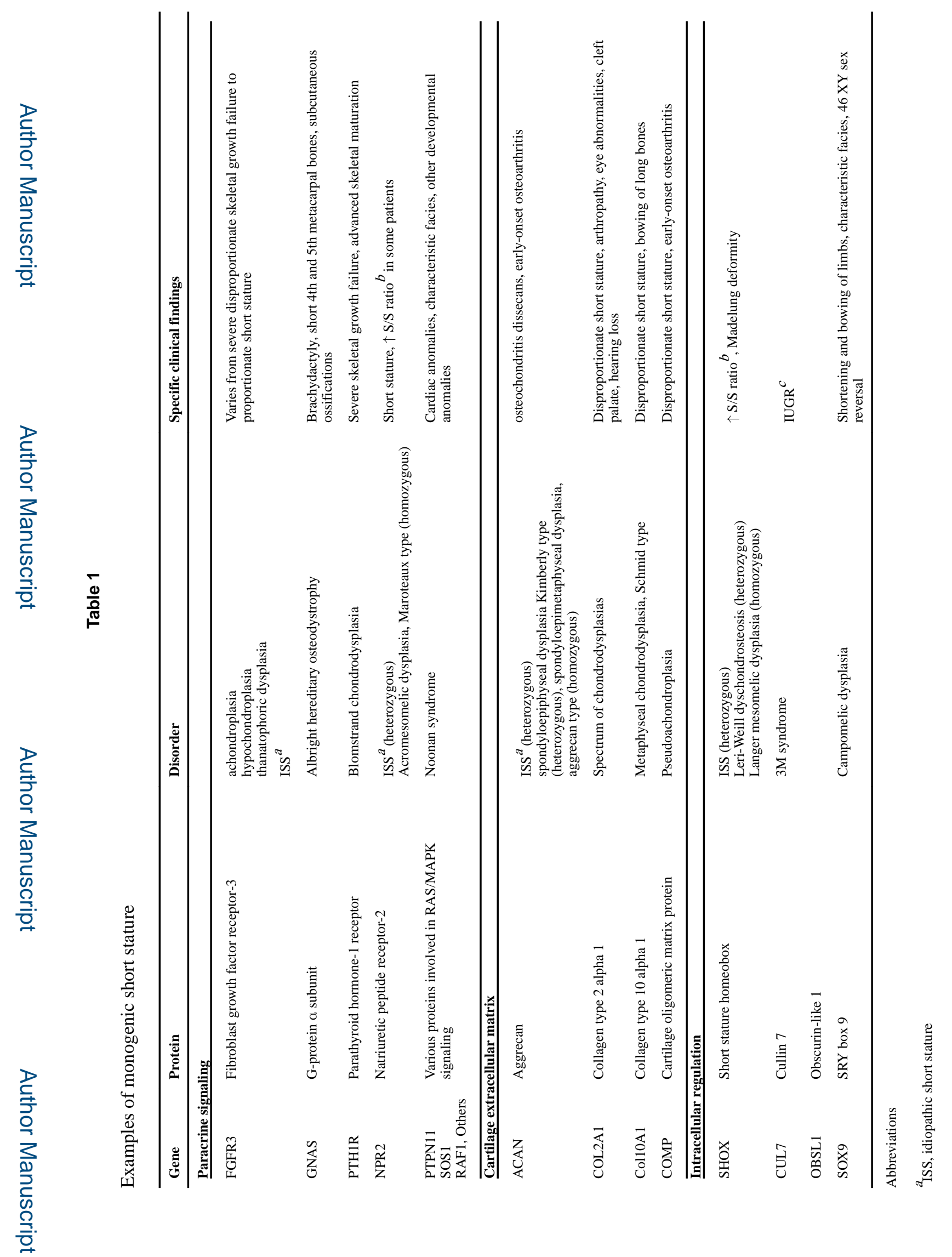

J Pediatr. Author manuscript; available in PMC 2017 June 01. 

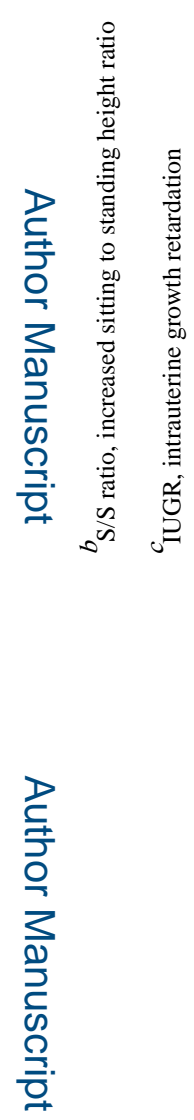

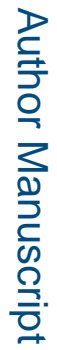

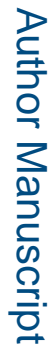

J Pediatr. Author manuscript; available in PMC 2017 June 01. 